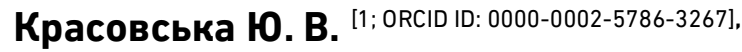
к.е.н., доцент

${ }^{1}$ Національний університет водного господарства та природокористування, м. Рівне

\title{
ВИКОРИСТАННЯ СТАТИСТИЧНИХ МЕТОДІВ В НАУКОВИХ ДОСЛІДЖЕННЯХ СТУДЕНТІВ ЕКОНОМІЧНОГО ФАХУ
}

У статті представлено системний аналіз використання статистичних методів на всіх етапах студентських наукових досліджень економічного спрямування. Описано критерії оцінки якості первинної інформації. Розкрито новітні підходи до перевірки достовірності інформації та перспективи використання сучасних модифікацій статистичних методів. Представлено перспективність поєднання статистичних та економікоматематичних методів для поглиблення результатів студентських наукових робіт. Наведено досвід використання статистичних методів та їх результативність в конкретному студентському дослідженні.

Ключові слова: наукове дослідження; статистичні методи; джерела інформації; етапи дослідження.

Вступ. 3 метою формування необхідних компетенцій, а також формування і підвищення кваліфікації, необхідної для отримання належного місця на ринку праці, протягом навчання у закладі вищої освіти студенти виконують різні за своїм характером, рівнем складності та змістом наукові дослідження. В зв'язку з цим науководослідна робота, що виконується з певної тематики і здійснюється поза навчальним процесом, дозволяє сформувати такі необхідні навички, як вміння самостійно формулювати завдання, здатність вибудовувати шлях до розв'язання конкретних проблем, аналітичні здібності, а також поглиблені здібності до саморозвитку і постійного самонавчання, тощо. Це суттєво підвищує рівень конкурентоспроможності майбутнього фахівця на ринку праці, 3 одного боку, і дозволяє сформувати багатогранну та всебічно розвинену особистість, з іншого. Проведення науково-дослідних робіт сприяє створенню наукового світогляду у майбутніх фахівців, надає допомогу у глибокому оволодінні спеціальністю та досягненні високого професіоналізму; розвитку наукового мислення та здібностей студентів у вирішенні практичних завдань, здатності застосовувати теоретичні знання у своїй практичній роботі, а також розширенню теоретичного кругозору і наукової ерудиції майбутнього фахівця. 
Аналіз останніх досліджень. Питанням методології проведення наукових досліджень приділено увагу в працях багатьох вчених, таких як Андрійчук В.Г., Білуха М. Т., Крушельницька О.В, Мазаракі А. А., Мочерний С. В., Попович І. В., Романенко С. С., Сурмін Ю. П., Франк Л. Фольфс тощо. Крім того, теоретичним та прикладним аспектам статистичного аналізу економічних явищ і процесів присвячено праці А.Головача, С.Герасименка, А. Єріної, О. Кулинича, Р. Кулинича, І. Манцурова, Н. Парфенцевої, О. Осауленка та інших вчених. У цій роботі проведено системний аналіз можливості залучення різноманітних методів статистичного дослідження (від традиційних до сучасних) на всіх етапах проведення студентського наукового дослідження.

Методика досліджень. При проведенні наукових досліджень студентами саме економічного спрямування слід пам'ятати, що навіть при використанні загальнонаукових методів (емпіричних та теоретичних) існує певна специфіка, обумовлена особливостями економічних явищ та процесів як об'єктів дослідження. Особливістю економічних досліджень $€$ те, що при їх проведенні, на відміну від інших наук, не можна застосувати спеціальне обладнання чи реактиви. Економічний процес $€$ просторово невизначеним і динамічним, тому саме метод абстракції дозволяє його уявити, описати, розібрати на складові з метою глибокого вивчення. За допомогою абстракції у процесі дослідження виявляють закономірності і зв'язки, пізнають сутність явищ і законів розвитку суспільства, визначають взаємозв'язки між економічними явищами прогнозують розвиток економічних процесів. В зв'язку з цим, більшість методів емпіричного дослідження набуває рис абстрактності. Наприклад, спостереження за коливаннями валютного курсу суттєво відрізняється від спостереження за протіканням хімічної реакції чи за змінами клімату в окремих регіонах. Велика кількість параметрів, що описують економічні явища, ускладнює процес використання методів вимірювання та порівняння. Проведення експерименту, зокрема, також вимагає набагато більших затрат ресурсів: фінансових, матеріальних, людських, інформаційних, а також часу, оскільки масштаби економічних експериментів завжди набагато більші і дуже часто менш передбачувані їх наслідки ніж порівняно з іншими науками. Навіть економічні моделі передбачають абстрагування і виділення основних категорій, у яких заховані важливіші ознаки явищ, що вивчаються, формулювання суттєвих ознак основних економічних категорій, логічне поєднання складових частин в абстрактні моделі і 
встановлення закономірностей розвитку явища через дослідження отриманих моделей. Що стосується теоретичних методів, то особливістю економічних досліджень можна вважати широке їх застосування на перших етапах і в тісній ув'язці з емпіричними, зокрема абстракція та історичний метод паралельно із спостереженням, аналіз та синтез у поєднанні з вимірюванням та порівнянням, індукція, дедукція та аналогії в сукупності 3 економічним експериментом тощо.

Крім того, як і кожна наука, економіка має цілий набір напрацьованих спеціальних методів, що дають можливість максимально повно розкривати потенціал наукових досліджень в цій сфері. Це: фотографування, хронометраж, методи елімінування та балансового зв'язку, методи техніко-економічних розрахунків та варіантних наближень, програмно-цільовий метод та економікоматематичне моделювання та інші. І особливе місце за поширеністю використання та широким спектром інструментів та засобів займають статистичні методи дослідження.

Результати досліджень. Використання сукупності статистичних методів супроводжує економічне наукове дослідження, в тому числі студентське, практично на всіх етапах. Узагальнюючи існуючі напрацювання [1; 2] можемо сформувати таку послідовність проведення наукового дослідження студентами економічного фаху: визначення проблеми та формулювання теми дослідження; ознайомлення 3 існуючими дослідженнями 3 обраної теми та попередній збір інформації; формування гіпотези та вибір методів дослідження, збір інформації та проведення досліджень; обробка даних, проведення експерименту та узагальнення наукових фактів; аналіз та оформлення результатів наукових досліджень; оприлюднення та впровадження наукових досліджень.

Вже на другому етапі, після формулювання теми дослідження, формування мети та завдань, окреслення об'єкта та предмета дослідження студент приступає до попереднього збору інформації. I на цьому етапі вже важливого значення набуває використання статистичних методів. Незважаючи на те що на даному етапі студент в основному працює з вторинною інформацією [3, С. 107-108], для формування достовірної гіпотези існує потреба у попередньому зборі також і первинної інформації, яка стосується об'єкта дослідження. Тому вже тут широкого розповсюдження набувають методи статистичного спостереження. При цьому для початкового етапу можна обмежитись вторинним спостереженням, тобто збиранням раніше зареєстрованих та оброблених даних, акцентуючи увагу на такій формі спостереження як звітність. Джерелами статистичної 
інформації, відповідно до Закону України «Про державну статистику» [4], можуть бути первинні та статистичні дані щодо респондентів, які підлягають статистичним спостереженням; офіційно опубліковані адміністративні дані державних органів, органів місцевого самоврядування, інших юридичних осіб; дані банківської, фінансової і митної статистики, статистики платіжного балансу тощо; статистичну інформацію міжнародних організацій та статистичних служб інших країн тощо; оцінки та розрахунки, здійснені на основі зазначених вище даних.

Наступним кроком в проведенні наукового дослідження $\epsilon$ формулювання гіпотези. В загальному вигляді наукова гіпотеза (не слід плутати зі статистичною гіпотезою) - це наукове передбачення або припущення, висунуте для пояснення будь-яких явищ, процесів, причин, які обумовили той чи інший шлях розвитку явища або процесу. Це свого роду ідея про існування тієї чи іншої закономірності, яка потребує підтвердження або спростування. Для того, щоб висунути гіпотезу дослідник повинен вже на даному етапі володіти певним набором статистичної інформації (отриманої на попередньому етапі), щоб зорієнтувати своє дослідження в необхідному напрямку. Тут в нагоді стають статистичні таблиці та графіки, а також метод статистичних групувань.

Сформулювавши гіпотезу, студент-дослідник конкретизує інформаційну базу дослідження і приступає до ретельного збору інформації. Тому на цьому етапі виникає потреба у залученні додатково до попередніх форм та методів також i первинного спостереження, а саме: проведення спеціально організованих спостережень та використання реєстрів. Найбільш розповсюдженими серед студентських наукових досліджень економічного спрямування $\epsilon$ документальний облік і робота зі звітністю, опитування кореспондентським та анкетним способами та робота 3 державними реєстрами. Оскільки від якості даних статистичного спостереження залежать результати подальшого дослідження, вони мають відповідати певним вимогам. Серед ключових вимог $€$ [3, С. 13]: вірогідність (достовірність) інформації, тобто відповідність реальному стану; повнота даних як за обсягом, так і по суті; своєчасність та актуальність, оскільки запізніла інформація втрачає користь; порівнянність даних у часі і просторі задля уникнення помилкового трактування результатів дослідження; доступність для забезпечення можливості користування нею та унеможливлення втрати економічної ефективності наукового дослідження тощо. 
Існують різні методи та способи оцінки достовірності інформації від психофізіологічних до моніторингових за критеріями балансу інформації, відокремлення фактів від думок, повноти та достовірності [5, С. 56-57]. Ми насамперед рекомендуємо студентам використовувати методи логічного та арифметичного контролю, а також співставлення даних з різних інформаційних джерел. Для оцінки достовірності вибіркових даних та ступеня їх репрезентативності, для підтвердження чи спростування статистичних гіпотез використовують суто статистичні методи, такі, як оцінка статистичної значущості результату. Нагадаємо, що статистична значущість (р-рівень значущості) - це вірогідність того, що отримані статистичні дані правильно представляють сукупність, яка досліджується. Традиційно вважають, що 95 або більше шансів зі 100 означають, що вірогідність правильності результатів достатньо висока для того, щоб їх поширювати. Математично рівень значущості (р) оцінюється навпаки як ймовірність того, що результати не є репрезентативними. Оскільки вірогідність помилки залежить від рівня статистичної значущості результатів, то чим менше значення $p$, тим більша впевненість у правильності результатів [6]. Така ймовірність обирається в якості вхідного параметру, а достовірність чи недостовірність статистичної гіпотези підтверджується за допомогою розрахунку статистичних критеріїв, наприклад, критерію Ст'юдента, Фішера, Z-критерію тощо [3, С. 95-97].

На етапі обробки даних та проведення дослідження в економічній сфері спектр використання статистичних методів $\epsilon$ надзвичайно широким. До статистичних методів обробки інформації відносять групування, розрахунок відносних і середніх величин, показники варіації, розробку таблиць, графічний метод, побудову динамічних рядів і розрахунок індексів. При проведенні власне досліджень 3 метою виявлення закономірностей використовується низка таких статистичних методів, як кореляційно-регресійні, методи оцінки інтенсивності та тенденцій розвитку економічних явищ або процесів.

На етапі проведення експериментів, моделюванні економічних явищ та процесів та узагальненні наукових фактів також широкого застосування мають статистичні методи названі в попередньому абзаці. Однак, крім них, на сучасному етапі розвитку науки з'являються і нові методи, що, використовуючи можливості комп'ютерної техніки, дають більш точні результати. Серед них можна виділити метод статистичних випробувань або метод МонтеКарло [7, С. 168-182]. Метод Монте-Карло - це метод імітації для приблизного відтворення реальних явищ. Він об'єднує аналіз 
чутливості (сприйнятливості) і аналіз розподілу ймовірностей вхідних змінних, отриманих на базі аналізу з використанням ЕОМ великого масиву статистичних даних. Цей метод дає змогу побудувати модель, спираючись на визначення функціональних залежностей у реальній системі. Після чого дає можливість одержати кількісний розв'язок, використовуючи теорію ймовірностей таблиці випадкових чисел. Перевагою цього методу $є$ можливість аналізувати і оцінювати різні сценарії розвитку економічного явища або процесу, враховуючи різні фактори в рамках одного підходу. При цьому кожен варіант розвитку подій має свій рівень ймовірності. Відкидаючи малоймовірні варіанти, дослідник має можливість визначити декілька найбільш вірогідних і тим самим підвищити рівень достовірності своїх висновків. Ще одним цікавим методом, який має гарні перспективи використання на цьому етапі дослідження, є метод статистичних ігор. Творцем теорії статистичних ігор вважається А. Вальд [8, С. 769-779]. Суть теорії статистичних ігор полягає в прийнятті оптимальних рішень в умовах невизначеності середовища (природи). Основними відмінностями статистичної гри від стратегічної $€$ відсутність прагнення до виграшу в гравцяприроди, тобто відсутність антагоністичного супротивника; можливість другого гравця-статистика провести статистичний експеримент для одержання додаткової інформації про стратегії природи. Застосування такого методу моделювання та оптимізації також дозволить досліднику підвищити достовірність результатів свого наукового пошуку. I нарешті, на етапі оформлення та представлення результатів наукових досліджень також стають в нагоді такі статистичні методи, як побудова таблиць та графіків.

Розглянемо процес використання статистичних методів в студентському науковому дослідженні на конкретному прикладі. В якості теми дослідження було обрано: «Дослідження впливу інфляції на розвиток малого бізнесу в Україні». Метою роботи було визначено вивчення та дослідження сутності інфляції, їі причин та аналіз впливу інфляційних процесів на ефективність діяльності малих підприємств. В якості завдань заплановано дослідити природу інфляції та причини її виникнення; оцінити динаміку показників діяльності малих підприємств, темпів інфляції в Україні; ступінь залежності показників діяльності суб'єктів малого бізнесу від темпів інфляції.

Після вивчення ступеня дослідженості даного питання в науковій літературі джерелах, було висунуто гіпотезу про те, що інтенсивність інфляційних процесів доволі істотно позначається на діяльності малих підприємств. Наступним кроком став вибір 
показників та джерел статистичної інформації. Для характеристики діяльності підприємств малого бізнесу в Україні було обрано систему кількісних та якісних показників: кількість суб'єктів малого підприємництва, обсяг реалізованої ними продукції, фінансовий результат до оподаткування та чистий прибуток, а також рівень рентабельності (збитковості) малих підприємств. Для оцінки темпів інфляції було обрано індекс споживчих цін. В якості джерела статистичної інформації використано офіційно опубліковані адміністративні дані Державної служби статистики України [9]. Для контролю за достовірністю даних, зокрема щодо індексу цін, проведено співставлення з іншим інформаційним джерелом [10].

Для економічної оцінки показників діяльності малого бізнесу в Україні, а також інтенсивності інфляції було використано методи і показники аналізу динаміки, в якості допоміжних - методи побудови таблиць та графіків [3, С. 123-128]. Зокрема в таблиці представлено результати динамічного аналізу рентабельності малих підприємств, а на рисунку - результати вивчення інтенсивності інфляції. Використання цих методів дало наступні результати: в 2010-2018 рр. відбулось скорочення кількості малих підприємств в Україні, щодо показників ефективності діяльності, то вони мали пікові від'ємні значення в період 2013-2015 рр., тоді як останні роки, особливо 2018, характеризувались позитивною динамікою прибутку та рентабельності. За досліджуваний період індекс споживчих цін в Україні зріс не суттєво з 109,1\% до 109,8\% з середнім абсолютним приростом 0,1\% щороку, однак спостерігається суттєва зміна цього показника в середині досліджуваного періоду: найменше значення він мав в 2012 році (індекс 99,8\% свідчить про зниження споживчих цін відносно 2011 року на 0,2\%), а найбільше - у 2015 (індекс 143,3\% показує зростання споживчих цін на 43,3\% порівняно з попереднім 2014 роком).

Подальше дослідження обумовило необхідність використати кореляційно регресійні методи аналізу. Зокрема, для оцінки щільності зв'язку між індексом інфляції та показниками діяльності підприємств було використано коефіцієнт кореляції Пірсона [3, С. 109]. Проведене таким чином дослідження показало наявність досить тісного зв'язку і негативний характер впливу індексу інфляції на показники прибутку та рентабельності: високий рівень інфляції математично обумовлює низькі значення зазначених показників, оскільки коефіцієнти кореляції коливаються від -0,6 (для фінансового результату до оподаткування та рентабельності) до -0,8 (для показника чистого прибутку). Це дає підстави для розробки моделі, яка математично може описати характер впливу інфляції на 
окремі показники розвитку малих підприємств, зокрема чистого прибутку.

Таблиця

Аналіз показників динаміки рентабельності діяльності малих підприємств України

\begin{tabular}{|c|c|c|c|c|}
\hline Роки & $\begin{array}{c}\text { Рівень } \\
\text { рентабельності } \\
\text { (збиткової) діяльності } \\
\text { підприємств, \% }\end{array}$ & $\begin{array}{c}\text { Абсолютний } \\
\text { приріст, \% }\end{array}$ & $\begin{array}{c}\text { Темп } \\
\text { росту,\% }\end{array}$ & $\begin{array}{c}\text { Темп } \\
\text { приросту, } \\
\%\end{array}$ \\
\hline 2010 & $-5,7$ & - & - & - \\
\hline 2011 & $-2,5$ & 3,2 & 43,9 & $-56,1$ \\
\hline 2012 & $-3,3$ & $-0,8$ & 132 & 32 \\
\hline 2013 & $-6,2$ & $-2,9$ & 187,9 & 87,9 \\
\hline 2014 & $-26,5$ & $-20,3$ & 427,4 & 327,4 \\
\hline 2015 & $-13,6$ & 12,9 & 51,3 & $-48,7$ \\
\hline 2016 & $-3,6$ & 10 & 26,5 & $-73,5$ \\
\hline 2017 & -2 & 1,6 & 55,6 & $-44,4$ \\
\hline 2018 & 2,7 & 4,7 & 235,0 & 135,0 \\
\hline Середні & $-6,7$ & 1,05 & 105,0 & 5,0 \\
значення & & & & \\
\hline
\end{tabular}

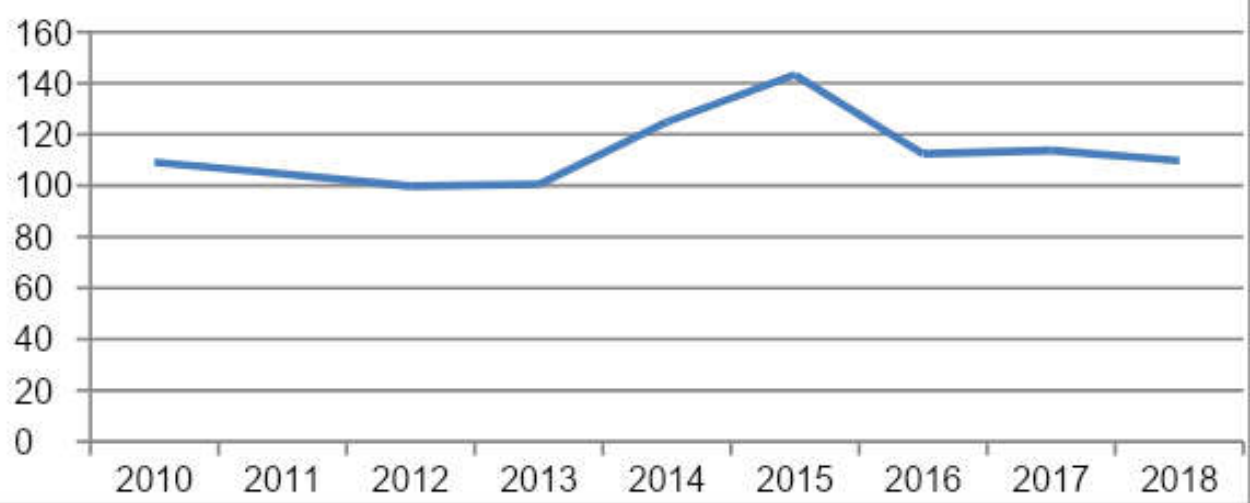

Рисунок. Динаміка індексу інфляції в Україні

Розрахунок параметрів такої моделі також здійснювався в рамках використання статистичних методів [3, С. 103-105] і дозволив отримати рівняння залежності чистого прибутку малих підприємств від індексу інфляції:

$$
y=339447,0-3386,9 \cdot x .
$$


Таку модель не можна використовувати для точного прогнозування чистого прибутку малих підприємств, оскільки вона враховує вплив лише одного фактору - інфляції, однак показує, що при кожному зростанні темпу інфляції на 1\% сукупний чистий прибуток малих підприємств в Україні зменшиться на 3386,9 млн грн. Для підтвердження істинності отриманих результатів проводиться перевірка істотності кореляційного зв'язку. Для чого розраховують критичне та фактичне значення коефіцієнта детермінації [3, С. 112-113], в даному прикладі критичне значення коефіцієнта детермінації при рівні значущості 5\% становить 0,444, а фактичне за результатами обчислень - 0,979. Оскільки фактичне значення більше ніж критичне, гіпотеза про існування стійкого оберненого зв'язку між індексом інфляції та чистим прибутком малих підприємств з ймовірністю 0,95 підтверджується.

Висновки. В умовах інтенсифікації науково-технічного прогресу проведення науково-дослідної роботи вимагає сучасних підходів та інтенсифікації навичок їх проведення. Виникає потреба в системному підході при використанні методів досліджень, в тому числі і статистичних. Такий підхід дозволить максимально повно використати потенціал зазначених методів, віднайти сфери застосування як традиційних так новітніх способів вивчення явищ та процесів студентів економічного фаху. Проведення оцінки достовірності інформації, використання інформаційних та комп'ютерних технологій на всіх етапах досліджень та сучасних модифікацій статистичних методів, розширення перспектив прогнозного підходу порівняно з ретроспективним - це ті моменти, які дадуть змогу підвищити достовірність результатів досліджень і рівень фахової підготовки майбутніх економістів.

1. Цехмістрова Г. С. Основи наукових досліджень : навч. посіб. Київ: Видавничий Дім «Слово», 2004. 240 с. 2. Гордійчук А. С., Стахів О.А. Основи наукових досліджень : навч. посіб. Рівне : НУВГП, 2008. 331 с. 3. Статистика : підручник / за наук. ред. С. С. Герасименка. 2-ге вид., перероб. і доп. К. : КНЕУ, 2000. 467 с. 4. Про державну статистику : Закон України. Відомості Верховної Ради України (ВВР). 1992. № 43. Ст. 608. 5. Аносов А. 0. Критерії моніторингу достовірності інформації в інформаційному просторі. URL: http://csecurity.kubg.edu.ua/index.php /journal/article/view/96/100 (дата звернення: 18.03.2020). 6. Will Koehrsen. Statistical Significance Explained. URL: https://towardsdatascience.com/statisticalsignificance-hypothesis-testing-the-normal-curve-and-p-values-93274fa32687 (дата звернення: 20.03.2020). 7. Кособуцький П. С. Статистичні та Монте-Карло алгоритми моделювання випадкових процесів у макро- i мікросистемах у MathCAD : монографія. Львів : Вид-во Львів. політехніки, 2014. 412 с. 8. Robert Aumann, Sergiu Hart. Handbook of Game Theory with Economic Applications. 9. Сайт Державної служби статистики України. URL: http://www.ukrstat.gov.ua/ (дата звернення: 20.03.2020). 10. Таблиця індексів інфляції за 2010-1019 р. Бухгалтер для 
працівників бюджетної сфери. URL: https://buhgalter.com.ua/dovidnik/normarobochogo-chasu/tablitsya-indeksiv-inflyatsiyi/ (дата звернення: 20.03.2020).

\section{REFERENCES:}

1. Tsekhmistrova H. S. Osnovy naukovykh doslidzhen : navch. posib. Kyiv : Vydavnychyi Dim «Slovo», 2004. 240 s. 2. Hordiichuk A. S., Stakhiv O. A. Osnovy naukovykh doslidzhen : navch. posib. Rivne : NUVHP, 2008. 331 s. 3. Statystyka : pidruchnyk / za nauk. red. S. S. Herasymenka. 2-he vyd., pererob. i dop. K. : KNEU, 2000.467 s. 4. Pro derzhavnu statystyku : Zakon Ukrainy. Vidomosti Verkhovnoi Rady Ukrainy (VVR). 1992. № 43. St. 608. 5. Anosov A. 0. Kryterii monitorynhu dostovirnosti informatsii $v$ informatsiinomu prostori. URL: http://csecurity.kubg.edu.ua/index.php /journal/article/view/96/100 (data zvernennia: 18.03.2020). 6. Will Koehrsen. Statistical Significance Explained. URL: https://towardsdatascience.com/statisticalsignificance-hypothesis-testing-the-normal-curve-and-p-values-93274fa32687 (data zvernennia: 20.03.2020). 7. Kosobutskyi P. S. Statystychni ta Monte-Karlo alhorytmy modeliuvannia vypadkovykh protsesiv u makro- i mikrosystemakh u MathCAD : monohrafiia. Lviv : Vyd-vo Lviv. politekhniky, 2014. 412 s. 8. Robert Aumann, Sergiu Hart. Handbook of Game Theory with Economic Applications. 9. Sait Derzhavnoi sluzhby statystyky Ukrainy. URL: http://www.ukrstat.gov.ua/ (data zvernennia: 20.03.2020). 10. Tablytsia indeksiv infliatsii za 2010-1019 r. Bukhhalter dlia pratsivnykiv biudzhetnoi sfery. URL: https://buhgalter.com.ua/dovidnik/normarobochogo-chasu/tablitsya-indeksiv-inflyatsiyi/ (data zvernennia: 20.03.2020).

Krasovska Y. V. [1; ORCID ID: 0000-0002-5786-3267], Candidate of Economics (Ph.D.), Associate Profesor

${ }^{1}$ National University of Water and Environmental Engineering, Rivne

\section{APPLICATION OF STATISTICAL METHODS IN SCIENTIFIC RESEARCH OF ECONOMICS STUDENTS}

Mastering the skills of scientific research is necessary for a specialist in economics in the acquisition of a wide range of knowledge, skills and competencies both in the professional field and in terms of general erudition. The high level of abstractness of economic phenomena and processes determines the specificity of the use of scientific methods in this field of knowledge. The statistical methods which accompany economic research practically at all stages of its carrying out occupy the special place. At the stage of substantiation of the research topic, methods of statistical collection of initial information are used. When formulating a hypothesis, statistical tables and graphs, as well as the method of statistical groupings are useful. Then the student begins to detail the information and assess its reliability, as well as to confirm or refute statistical hypotheses, and here uses statistical methods such as assessing the statistical significance of the result by calculating statistical criteria, such as Student's, Fisher's, Z- 
criteria, etc. When conducting actual research in order to identify patterns, a number of such statistical methods are used as: correlation and regression, methods for estimating the intensity and trends. In addition to traditional methods at the present stage of development of science, new methods are becoming popular that use the capabilities of computer technology and give more accurate results.

This paper presents an example of the use of statistical methods in conducting a student study of the impact of inflation on the development of small business in Ukraine. It was hypothesized that the intensity of inflation processes has a significant impact on the activities of small enterprises. After using such methods as: statistical observation, time series analysis, correlation-regression analysis and statistical testing of hypotheses with a probability of $\mathbf{0 . 9 5}$, it was confirmed that with each increase in inflation, the total net profit of small enterprises decreases significantly.

Keywords: scientific research; statistical methods; sources of information; stages of research.

Красовская Ю. В. [1; ORCID ID: 0000-0002-5786-3267], к.э.н., доцент

${ }^{1}$ Национальный университет водного хозяйства и природопользования, г. Ровно

\title{
ИСПОЛЬЗОВАНИЕ СТАТИСТИЧЕСКИХ МЕТОДОВ В НАУЧНЫХ ИССЛЕДОВАНИЯХ СТУДЕНТОВ ЭКОНОМИЧЕСКИХ СПЕЦИАЛЬНОСТЕЙ
}

\begin{abstract}
В статье представлен системный анализ использования статистических методов на всех этапах студенческих научных исследованиях экономического направления. Описаны критерии оценки качества первичной информации. Раскрыты новейшие подходы к проверке достоверности информации и перспективы использования современных модификаций статистических методов. Представлена перспективность совместного использования статистических и экономико-математических методов для углубления результатов студенческих научных работ. Показан опыт использования статистических методов и их результативность на конкретном примере.
\end{abstract}

Ключевые слова: научное исследование; статистические методы; источники информации; этапы исследований. 